https://doi.org/10.17816/MAJ191S172-74

\title{
INFLUENCE OF ENDOCRINE PATHOLOGY ON NEUROIMMOUNS INTERACTIONS IN PLACENTA
}

\author{
A.O. Drobintseva ${ }^{1,2}$, A.E. Andreev ${ }^{1,2}$, S.V. Makarenko ${ }^{2}$, D.S. Medvedev ${ }^{2}$, Y.A. Soldatova ${ }^{2}$, \\ V.O. Polyakova ${ }^{1,2,3}$
}

${ }^{1}$ Research Institute of Obstetrics, Gynecology and Reproductology named after D.O. Ott, Saint Petersburg, Russia;

${ }^{2}$ Saint Petersburg Medical and Social Institute, Saint Petersburg, Russia;

${ }^{3}$ Saint Petersburg State University, Saint Petersburg, Russia

\section{ВЛИЯНИЕ ПАТОЛОГИИ ЭНДОКРИННОЙ СИСТЕМЫ НА НЕЙРОИММУННЫЕ ВЗАИМОДЕЙСТВИЯ В ПЛАЦЕНТЕ}

\author{
А.О. Дробинцева ${ }^{1,2}$, А.Е. Андреев ${ }^{1,2}$, С.В. Макаренко ${ }^{2}$, Д.С. Медведев ${ }^{2}$, Я.А. Солдатова ${ }^{2}$, \\ В.О. Полякова ${ }^{1,2,3}$ \\ ${ }^{1}$ ФГБНУ «НИИ акушерства, гинекологии и репродуктологии им. Д.О. Отта», Санкт-Петербург; \\ ${ }^{2}$ Санкт-Петербургский медико-социальный институт, Санкт-Петербург; \\ ${ }^{3}$ Санкт-Петербургский государственный университет, Санкт-Петербург
}

According to statistics, approximately $75-80 \%$ of cases of diabetes mellitus in women during pregnancy show the presence of a urogenital infection in which the development of the inflammatory process is conducive to the elimination of the pathogen and the appearance of necrotic tissue. Such inflammatory processes, as a rule, occur with the participation of macrophages attracted by B-lymphocytes and NK-cells. The main goal of this study was to evaluate the expression ratio of immunocompetent cells: macrophages, NK cells and B lymphocytes in the placenta in women with diabetes mellitus who are in different age groups. Molecular markers were visualized using an immunoistochemical method. Were used antibodies to CD68 (1:300, Dako, USA) for macrophages, CD20 (1:300, Dako, USA) for B-lymphocytes and CD57 (1:300, Dako, USA) for natural killer cells. The results were visualized on a confocal microscope (FluoView 1000 (Olympus)). For scoring of microphotographs program "Morphology 5.2" was used. On the microphotographs the relative area of expression was evaluated, signified as the ratio of the area of the immunopositive reaction to the total area of the slide and the optical density. Then a statistical evaluation of the obtained data in the "Statistic 10.0" program was carried out. During the experiment, a sharp decrease in the expression of the CD68 marker in the placenta was detected. A decrease in the expression of the CD20 marker with an increase in the age of patients with diabetes mellitus was also demonstrated, while in healthy women an increase was observed in the middle age group. For natural killers, there was no difference between healthy and sick women. The result indicates a weakening of the reaction of the immune system in diabetes mellitus.

Keywords: natural killer cells; B-lymphocytes; macrophages; diabetes mellitus; placenta; immune system.

По статистическим данным приблизительно в 75-80\% случаев сахарного диабета у женщин при беременности наблюдается наличие урогенитальной инфекции, при которой происходит развитие воспалительного процесса способствующего ликвидации патогена и возникновению некротизированной ткани. Такие воспалительные процессы, как правило, происходят при участии макрофагов, привлекаемых В-лимфоцитами и НК-клетками.

Основной целью приведенного исследования было оценить соотношение экспрессии иммунокомпетентных клеток: макрофагов, НК-клеток и В-лимфоцитов в плаценте у женщин с сахарным диабетом, находящихся в разных возрастных группах. Визуализация молекулярных маркеров производилась с применением иммуногоистохимического метода. В качестве антител использовались антитела к CD68 (1:300, Dako, CША) для макрофагов, CD20 (1:300, Dako, США) для В-лимфоцитов и CD57 ( $1: 300$, Dako, CША) для натуральных киллеров. Визуализация результатов производилась на конфокальном микроскопе (FluoView 1000 (Olympus)). Для оценки полученных изображений применялись программы «морфология 5.2». На изображениях оценивались относительная площадь экспрессии и оптическая плотность. Затем проводилась статистическая оценка полученных данных в программе «Statistic 6.0».

B процессе эксперимента было выявлено резкое снижения экспрессии маркера CD68 в плаценте. Также было продемонстрировано снижение экспрессии маркера CD20 при увеличении возраста пациенток при сахарном диабете, тогда как у здоровых женщин наблюдалось увеличение в средней возрастной группе. Для натуральных киллеров различий между здоровыми и больными женщинами не наблюдалось. Полученный результат свидетельствует об ослабление реакции иммунной системы при сахарном диабете.

Ключевые слова: естественные клетки-киллеры; В-лимфоциты; макрофаги; сахарный диабет; плацента; иммунная система. 
Introduction. According to literature, during pregnancy in women with concomitant disease such as diabetes mellitus in $75-80 \%$ of cases urogenital infection is verified, which is accompanied by inflammation and the occurrence of necrotic areas $[1-3]$. As a rule, inflammatory processes caused by the participation of macrophages attracted by B lymphocytes and NK cells. Placental macrophages - the main immunocompetent cells in the placenta that carry out reactions of innate immunity. According to numerous literature data, the number of macrophages during the whole pregnancy does not change $[1,3]$. Another component of the maternal immune response to infection is natural killer cells (NK cells), it is known that these cells in the mature placenta are extremely rarely verified. B-lymphocytes belong to adaptive immunity and are almost completely absent in the placenta [2].

The aim of this work is to study the equilibration of immunocompetent cells: macrophages, NK cells and B lymphocytes in the placenta of women with diabetes mellitus different age groups.

Material and metods. The material for the study was the placenta taken from women belonging to two nosological groups. The first group consisted of women with an established $\mathrm{f}$ diabetes, the second - the control group (healthy). Each group included 30 people. Both groups were further divided into 3 age periods $-18-28,29-35$ and 36-40 years, respectively.

Molecular markers were visualized using an immunoistochemical method. Were used antibodies to CD68 (1:300, Dako, USA) for macrophages, CD20 (1:300, Dako, USA) for B-lymphocytes and CD57 (1:300, Dako, USA) for natural killer cells. The results were visualized on a confocal microscope (FluoView 1000 (Olympus)). For scoring of microphotographs program "Morphology 5.2" was used. On the microphotographs the relative area of expression was evaluated, signified as the ratio of the area of the immunopositive reaction to the total area of the slide and the optical density. Then a statistical evaluation of the obtained data in the "Statistic 10.0" program was carried out.
Results and discussion. During the experiment, the presence of macrophages in control group was revealed, exclusively in the first age group. Their relative area expression was approximately $0.90 \pm 0.3 \%$. In the second and third age groups, macrophages were not verified. In the placenta of diabetic women, a significant decrease in the level of macrophages with increasing age of the patients was recorded. This indicator was $2.90 \pm 0.89 \%$, $2.20 \pm 0.67 \%, 1.81 \pm 0.43 \%$ for groups $18-28$, $29-35$ and $36-40$ years, respectively.

In terms of optical density in the control group, there were no significant differences in the expression of the CD20 marker between women of different age groups 18-28 and 29-35 years, however a significant decrease in this indicator was detected in the group of women of the older age $-36-40$ years. For all 3 age groups, the optical density was $0.26 \pm 0.09 \%, 0.25 \pm 0.05 \%$, $0.12 \pm 0.1 \%$, respectively. In the experimental group, twice increase in the expression index of CD20 in women aged 29-35 years, which was $0.9 \pm 0.07 \%$, was found; there were no differences between the groups of $18-28$ and 36-40 years.

The expression of the CD57 marker in both groups was positively correlated with an increase in the age of the patients. For the control group, the optical density index was $0.1 \pm 0.03 \%, 0.18 \pm 0.06 \%$ and $0.43 \pm 0.09 \%$. The index of optical density in placenta of women with diabetes tendency to decrease was revealed compared to the first group and was equal to $0.16 \pm 0.01 \%, 0.2 \pm 0.05 \%$ and $0.47 \pm 0.1 \%$, respectively.

Conclusion. The results obtained in investigation suggest that diabetes mellitus, during pregnancy, reduces immune responses not only locally, but also in the body as a whole. This trend is manifest as a sharp decrease in the expression of the CD68 marker in the placenta. The study showed a significant decrease in the expression of the CD20 marker, correlating with an increase in the age of patients with diabetes mellitus, whereas in women with uncomplicated pregnancy an increase in the B-lymphocyte marker was observed in the middle age group. For natural killers, no significant differences in the studied groups were verified.

\section{References}

1. Edu A, Teodorescu C, Dobjanschi CG, et al. Placenta changes in pregnancy with gestational diabetes. Rom J Morphol Embryol. 2016;57(2):507-12.

2. Radaelli T, Varastehpour A, Catalano P, Hauguel-de Mouzon S. Gestational diabetes induces placental genes for chronic stress and inflammatory pathways. Diabetes. 2003;52(12):2951-2958.

3. Jun Y, Yong Z, Juan G, et al. Assessment of the number and function of macrophages in the placenta of gestational diabetes mellitus patients. Journal of Huazhong University of Science and Technology. 2013;33(5):725-729. 